\begin{tabular}{|c|c|c|c|c|c|c|c|c|}
\hline \multicolumn{3}{|c|}{$\begin{array}{l}\text { 2. To: (Receiving Organization) } \\
\text { Distribution }\end{array}$} & \multicolumn{2}{|c|}{ 3. From: (Originating Organization) } & \multicolumn{4}{|c|}{ 4. Related EDT No.: } \\
\hline \multicolumn{3}{|c|}{ CSB Shippingport FSAR - SNF } & \multicolumn{2}{|c|}{ 6. Design Authority/ Design Agent/Cog. Engr.: } & \multicolumn{4}{|c|}{$\begin{array}{r}\text { 7. Purchase Order No.: } \\
\text { N/A }\end{array}$} \\
\hline \multicolumn{5}{|c|}{ 8. Originator Remarks: } & \multicolumn{4}{|c|}{$\begin{array}{r}\text { 9. Equip/Component No:: } \\
\text { N/A }\end{array}$} \\
\hline \multicolumn{5}{|c|}{ Transmittal for approval and release. } & \multicolumn{4}{|c|}{$\begin{array}{r}\text { 10. System/Bldg./Facility: } \\
\text { N/A }\end{array}$} \\
\hline \multirow{3}{*}{\multicolumn{3}{|c|}{ 11. Receiver Remarks: }} & \multirow{3}{*}{\multicolumn{2}{|c|}{ Document? [] Yes [x] No }} & \multicolumn{4}{|c|}{$\begin{array}{r}\text { 12. Major Assm. Dwg. No.: } \\
\text { N/A }\end{array}$} \\
\hline & & & & & \multicolumn{4}{|c|}{ 13. Permit/Permit Application No.: } \\
\hline & & & & & \multicolumn{4}{|c|}{$\begin{array}{r}\text { 14. Required Response Date: } \\
\text { N/A }\end{array}$} \\
\hline \multicolumn{2}{|l|}{15.} & \multicolumn{3}{|c|}{ DATA TRANSMITTED } & (F) & (G) & $(\mathrm{H})$ & (l) \\
\hline $\begin{array}{l}\text { (A) } \\
\text { ltern } \\
\text { No. }\end{array}$ & (B) Document/Drawing No. & $\begin{array}{l}\text { (C) } \\
\text { Sheet } \\
\text { No. }\end{array}$ & $\begin{array}{l}\text { (D) } \\
\text { Rev. } \\
\text { No. }\end{array}$ & (E) Titite or Description of Data Transminted & $\begin{array}{l}\text { Approval } \\
\text { Designator }\end{array}$ & $\begin{array}{l}\text { Reason } \\
\text { for Trans- } \\
\text { mittal }\end{array}$ & $\begin{array}{l}\text { Origi- } \\
\text { nator } \\
\text { Dispo- } \\
\text { sition } \\
\end{array}$ & $\begin{array}{c}\text { Receiver } \\
\text { Disposition }\end{array}$ \\
\hline 1 & SNF-5808 & N/A & 0 & $\begin{array}{l}\text { ALARA Analysis for } \\
\text { Shippingport Pressurized Water } \\
\text { Reactor Core } 2 \text { Fuel Storage in } \\
\text { the Canister Storage Building }\end{array}$ & $\mathrm{S}, \mathrm{Q}$ & 1,2 & 1 & 1 \\
\hline & & & & & & & & \\
\hline & & & & & & & & \\
\hline & & & & & & & & \\
\hline & & & & & & & & \\
\hline & & & & & & & & \\
\hline
\end{tabular}

\begin{tabular}{|c|c|c|c|c|c|c|}
\hline \multicolumn{7}{|c|}{ KEY } \\
\hline \multirow{2}{*}{\multicolumn{3}{|c|}{$\begin{array}{l}\text { Approval Designator (F) } \\
\text { E, S. Q, Dor N/A } \\
\text { (see WHC-CM-3-S, Sec. 12.7) }\end{array}$}} & \multirow{2}{*}{\multicolumn{2}{|c|}{$\begin{array}{l}\text { Reason for Transmittal (G) } \\
\text { 4. Review } \\
\text { 5. Post-Review } \\
\text { 6. Dist (Receipt Acknow. Required) }\end{array}$}} & \multicolumn{2}{|r|}{ Disposition (H) \& (n) } \\
\hline & & & & & \multicolumn{2}{|c|}{$\begin{array}{ll}\text { 1. Approved } & \text { 4. Reviewed no/comment } \\
\text { 2. Approved w/comment } & \text { 5. Reviewed w/comment } \\
\text { 3. Disapproved w/comment } & \text { 6. Receipt acknowledged } \\
\end{array}$} \\
\hline \multicolumn{7}{|c|}{$\begin{array}{l}\text { 17. SIGNATUREDISTRIBUTTION } \\
\text { (See Approval Designator for required signatures) }\end{array}$} \\
\hline $\begin{array}{l}\text { (G) } \\
\text { Reason }\end{array}$ & 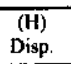 & & 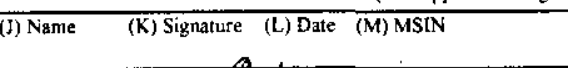 & $\begin{array}{c}\text { (G) } \\
\text { Reason }\end{array}$ & $\begin{array}{ll}\text { (H) } \\
\text { Disp. }\end{array}$ & (K) Signature (L) Date (M) MSIN \\
\hline $1-2$ & 1 & Desig & hority D Johnson then $3 / 2 y / c, \quad$ R3-I I & $1-2$ & 1 & Radiological Controls CA Bullock CA Butlonk X3-68 \\
\hline $1-2$ & 1 & Desig & 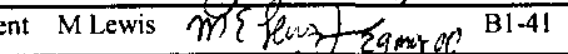 & $1-2$ & $l$ & CSB Operations O.M. Serrano / fee \\
\hline $1-2$ & 1 & $\operatorname{Cog}$ & 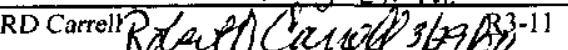 & & & 0004 \\
\hline $1-2$ & 1 & $\operatorname{Cog}$ & 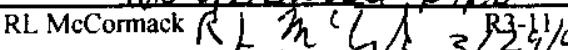 & & & \\
\hline $1-2$ & 1 & QA & imith $D W S$ Suth $/ 476 / 00 \quad$ \$2-48 & & & \\
\hline \multirow[t]{2}{*}{$1-2$} & l & Whucle & fety RL Garreft $X+1$ & & & \\
\hline & & & $J$ & & & \\
\hline
\end{tabular}
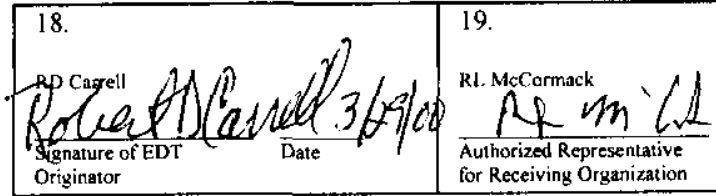

20

RL M Design Authority Cognizant Manager
21. DOE APPROVAL (if required)

Ctrl. No.

[] Approved

3/29/00 [] Approved w/comments

[] Disapproved w/comments

BD-7400-172-2 (05/96) GEF097 


\section{ALARA Analysis for Shippingport Pressurized Water Reactor Core 2 Fuel Storage in the Canister Storage Building}

Prepared for the U.S. Department of Energy

Assistant Secretary for Environmental Management

Project Hanford Management Contractor for the

U.S. Department of Energy under Contract DE-AC06-96RL13200

Fluor Hanford

P.o. Box 1000

Richland, Washington 
SNF-5808

Revision 0

EDT 629068

\section{ALARA Analysis for Shippingport Pressurized Water Reactor Core 2 Fuel Storage in the Canister Storage Building}

M. Lewis

Technical Resources International, Inc.

1835 Terminal Drive, Suite 120, Richland, WA 99352

Date Published

March 2000

Prepared for the U.S. Department of Energy

Assistant Secretary for Environmental Management

Project Hanford Management Contractor for the

U.S. Department of Energy under Contract DE-AC06-96RL13200

Fluor Hanford

P.O. Box 1000

Richland, Washington
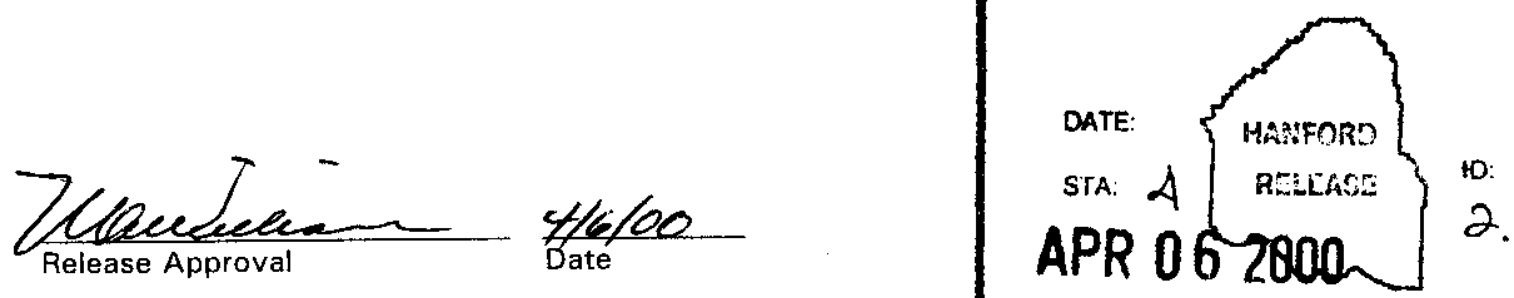

31 total Pages. 
SNF-5808, Rev. 0

Key Words:

200 Area Canister Storage Building, Shippingport PWR Core 2 Fuel, Spent Nuclear Fuel, SSFC, CSB

\begin{abstract}
:
The addition of Shippingport Pressurized Water Reactor (PWR) Core 2 Blanket Fuel Assembly storage in the Canister Storage Building (CSB) will increase the total cumulative CSB personnel exposure from receipt and handling activities. The loaded Shippingport Spent Fuel Canisters (SSFCs) used for the Shippingport fuel have a higher external dose rate. Assuming an MCO handling rate of 170 per year (K East and $\mathrm{K}$ West concurrent operation), 24-hr CSB operation, and nominal SSFC loading, all work crew personnel will have a cumulative annual exposure of less than the 1,000 mrem limit.
\end{abstract}




\section{LEGAL DISCLAIMER}

This report was prepared as an account of work sponsored by an agency of the United States Government. Neither the United States Government nor any agency thereof, nor any of their employees, nor any of their contractors, subcontractors or their employees, makes any warranty, express or implied, or assumes any legal liability or responsibility for the accuracy, completeness, or any third party's use or the results of such use of any information, apparatus, product, or process

disclosed, or represents that its use would not infringe privately owned rights. Reference herein to any specific commercial product, process, or service by trade name, trademark, manufacturer, or otherwise, does not necessarily constitute or imply its endorsement, recommendation, or favoring by the United States Government or any agency thereof or its contractors or subcontractors. The views and opinions of authors expressed herein do not necessarily state or reflect those of the United States Government or any agency thereof.

This report has been reproduced from the best available copy. 


\section{ALARA ANALYSIS FOR \\ SHIPPINGPORT PRESSURIZED WATER REACTOR CORE 2 FUEL STORAGE \\ IN THE \\ CANISTER STORAGE BUILDING}

Prepared by: Technical Resources International, Inc

1835 Terminal Drive, Suite 120

Richland, WA 99352 
SNF-5808, REV 0

This page intentionally left blank. 


\section{CONTENTS}

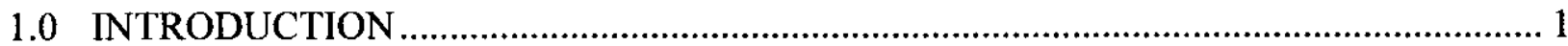

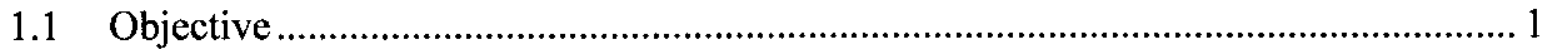

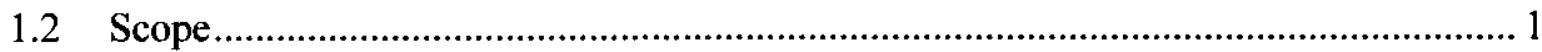

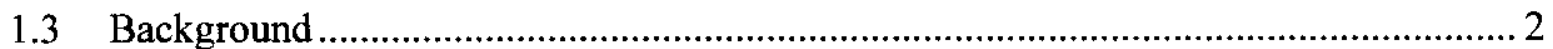

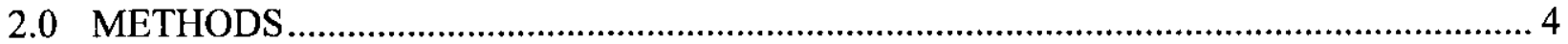

2.1 Dose Rate Calculations for Shippingport Spent Fuel Canister Operations ................. 4

3.0 RESULTS, OPTIONS, AND CONSIDERATIONS ................................................... 7

3.1 Shielding Shippingport Spent Fuel Canister..................................................... 7

3.2 Shielding in the Canister Storage Building ........................................................ 8

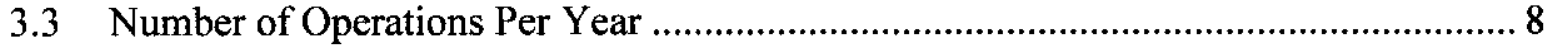

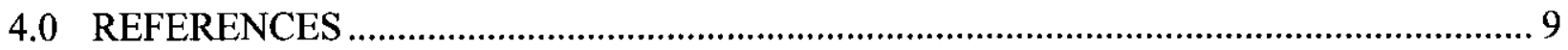

APPENDIX A - SHIPPINGPORT SPENT FUEL CANISTER EVALUATIONS FOR MAXIMUM FUEL LOADING ........................................................... A-1

APPENDIX B - OPERATIONAL SEQUENCE BLOCK FLOW DIAGRAMS........................ 
SNF-5808, REV 0

\section{LIST OF FIGURES}

Figure 1-1. Shippingport Pressurized Water Reactor Core 2 Blanket Fuel Assembly 3

\section{LIST OF TABLES}

Table 2-1. Source: Irradiated Uranium and Cladding Nominal Loading Radial - MultiCanister Overpack Inside Lidded Cask

Table 2-2. Source: Irradiated Uranium and Cladding Nominal Loading Top - Multi-Canister Overpack Inside Lidded Cask.

Table 2-3. Source: Irradiated Uranium and Cladding Nominal Loading Top - Multi-Canister Overpack Inside Cask, No Lid............................................................................... 5

Table 2-4. Gamma Source: Irradiated Top Extension Bracket..................................................... 6

Table 2-5. One Year - Nominal Shippingport Spent Fuel Canister Exposure ............................... 7 
SNF-5808, REV 0

\section{LIST OF TERMS}

$\begin{array}{ll}\text { ALARA } & \text { as low as reasonably achievable } \\ \text { CSB } & \text { Canister Storage Building } \\ \text { MCNP } & \text { Monte Carlo n-particle } \\ \text { MCO } & \text { multi-canister overpack } \\ \text { MHM } & \text { multi-canister overpack handling machine } \\ \text { PWR } & \text { pressurized water reactor } \\ \text { SSFC } & \text { Shippingport Spent Fuel Canister }\end{array}$


SNF-5808, REV 0

This page intentionally left blank. 


\section{ALARA ANALYSIS FOR SHIPPINGPORT PRESSURIZED WATER REACTOR CORE 2 FUEL STORAGE IN THE CANISTER STORAGE BUILDING}

\section{SUMMARY}

The addition of Shippingport Pressurized Water Reactor (PWR) Core 2 Blanket Fuel Assembly storage in the Canister Storage Building (CSB) will increase the total cumulative CSB personnel exposure from receipt and handling activities. The loaded Shippingport Spent Fuel Canisters (SSFCs) used for the Shippingport fuel have a higher external dose rate by a factor of approximately three, primarily the result of a substantially higher neutron exposure dose rate. Several crew member groups could exceed $1,000 \mathrm{mrem} /$ year when the operations are analyzed for worst case maximum fuel loading and assuming a proposed handling rate of 200 multicanister overpacks (MCOs) per year, plus all 18 SSFCs in one year. These groups are operators, health physics technicians, and inspection personnel. Nominal fuel loading of the additional SSFCs could result in the operators exceeding $1,000 \mathrm{mrem} /$ year, assuming a proposed handling rate of $200 \mathrm{MCOs}$ per year. More recent MCO handling rates are estimated to be fewer per year, which would decrease personnel annual exposures without decreasing the total exposure for the project. Assuming an MCO handling rate of 170 per year (K East and K West concurrent operation), 24-hr CSB operation, and nominal SSFC loading, all work crew personnel will have a cumulative annual exposure of less than 1,000 mrem. Additional external shielding of the SSFC is not an option due to size restrictions. Additional shielding for the CSB facility is not warranted due to the relatively short exposure time frames involved, and potential exposures could be mitigated with administrative controls.

\subsection{INTRODUCTION}

\subsection{OBJECTIVE}

The objective of this ALARA (as low as reasonably achievable) analysis is to determine the annual personnel exposure at the CSB due to handling and storing Shippingport PWR Core 2 fuel in 18 additional SSFCs. All handling activities are assumed to occur during a single year. The impact on the CSB cumulative annual personnel exposure is also assessed.

\subsection{SCOPE}

This analysis is limited to the estimation of facility personnel exposures during receipt, cap welding, and staging for the storage of 18 SSFCs. No other hazardous agents have been determined to be of concern during these operations. Off-normal/recovery operations or accident 
conditions are not within the scope of this analysis; however, a $10 \%$ increase in exposure was included to account for any abnormal operations.

\subsection{BACKGROUND}

There are currently 72 Shippingport PWR Core 2 blanket fuel assemblies in underwater storage racks in a converted cell in the 221-T Canyon. These assemblies are to be removed from the T-Plant for long-term dry storage in the CSB. The assemblies will be removed from the pool, allowed to drain and dry, and then loaded into an SSFC within a TN-WHC transport cask on a transport trailer in the T-Plant canyon railroad tunnel. When loaded, each SSFC will have its shield plug installed and will be backfilled with helium, vacuum checked, and leak tested prior to transport to the CSB. All CSB mechanical handling and operations will be the same as for the N Reactor fuel in MCOs from the Cold Vacuum Drying Facility.

Eighteen MCOs will be purchased and modified to contain four Shippingport PWR Core 2 blanket fuel assemblies. The basic MCO, without the center process tube, is adequate to adapt for the SSFC, except that the cavity height is about two inches short. Since the SSFC will not require the canister internal filters, the required cavity space can be readily obtained by their removal and by modifying the shield plug. An additional 2 -in thick shield plate is also welded to the bottom of the shield plug.

The Shippingport PWR Core 2 fuel was a developmental fuel in the U. S. Energy Research and Development Administration (now the U.S. Department of Energy) light water breeder reactor research program. Core 2 was the second of three cores irradiated in the Shippingport Atomic Power Station at Shippingport, Pennsylvania. The major purpose of the Shippingport project was to advance reactor technology and breeder reactor technology. The core was arranged into separate "seed" and "blanket" assemblies (present terminology would probably be "driver" and "target"). The seed assemblies were highly enriched uranium in uranium oxide mixed with zirconium oxide ceramic fuel $\left(\mathrm{UO}_{2}-\mathrm{ZrO}_{2}\right)$, which provided the neutron source. The blanket assemblies were natural uranium oxide $\left(\mathrm{UO}_{2}\right)$ for breeding purposes. The blanket assemblies were arranged to be in close proximity to the seed assemblies. Seventy-two standard blanket assemblies were shipped to the Hanford Site during 1978 and 1979 and have since been stored underwater in the 221-T Canyon.

The 72 standard blanket assemblies are 142.3 in. long and have a 7.5-in. square crosssection (SNF-5809). The assemblies contain three basic linear sections that are bolted together: an extended fuel cluster in the middle, and top and bottom extension brackets. The fuel cluster is clad with Zircaloy-4. The bracket extensions are made of 304 stainless steel. Each assembly weighs approximately $1,180 \mathrm{lbs}$.

The fuel cluster consists of two identical oxide fuel plate subassemblies welded together to form a square structure, with two Zircaloy-43 cluster extensions welded to the ends of the subassemblies. Each subassembly consists of 30 compartmented fuel plates and two Zircaloy-4 end plates welded together to form parallel coolant channels. The fuel plate design includes many small ceramic fuel wafers surrounded by a Zircaloy-4 grid to provide adequate structural strength. The wafers have a pyrolytic carbon coating that prevented the zirconium from reacting 
chemically with the uranium oxide (WAPD-296). The upper and lower halves of the extended fuel cluster are mirror images.

The minor differences in the top and bottom extension brackets between blanket assemblies are due to the two-pass flow arrangement used to optimize heat transfer in the reactor core. The top extension brackets are identical, except for the location of the cooling water outlet passages. The bottom extensions brackets are basically the same, except for key slots to prevent inserting an assembly into the wrong cooling water pass location. A Shippingport PWR Core 2 blanket fuel assembly is shown in Figure 1-1.

Figure 1-1. Shippingport Pressurized Water Reactor Core 2 Blanket Fuel Assembly

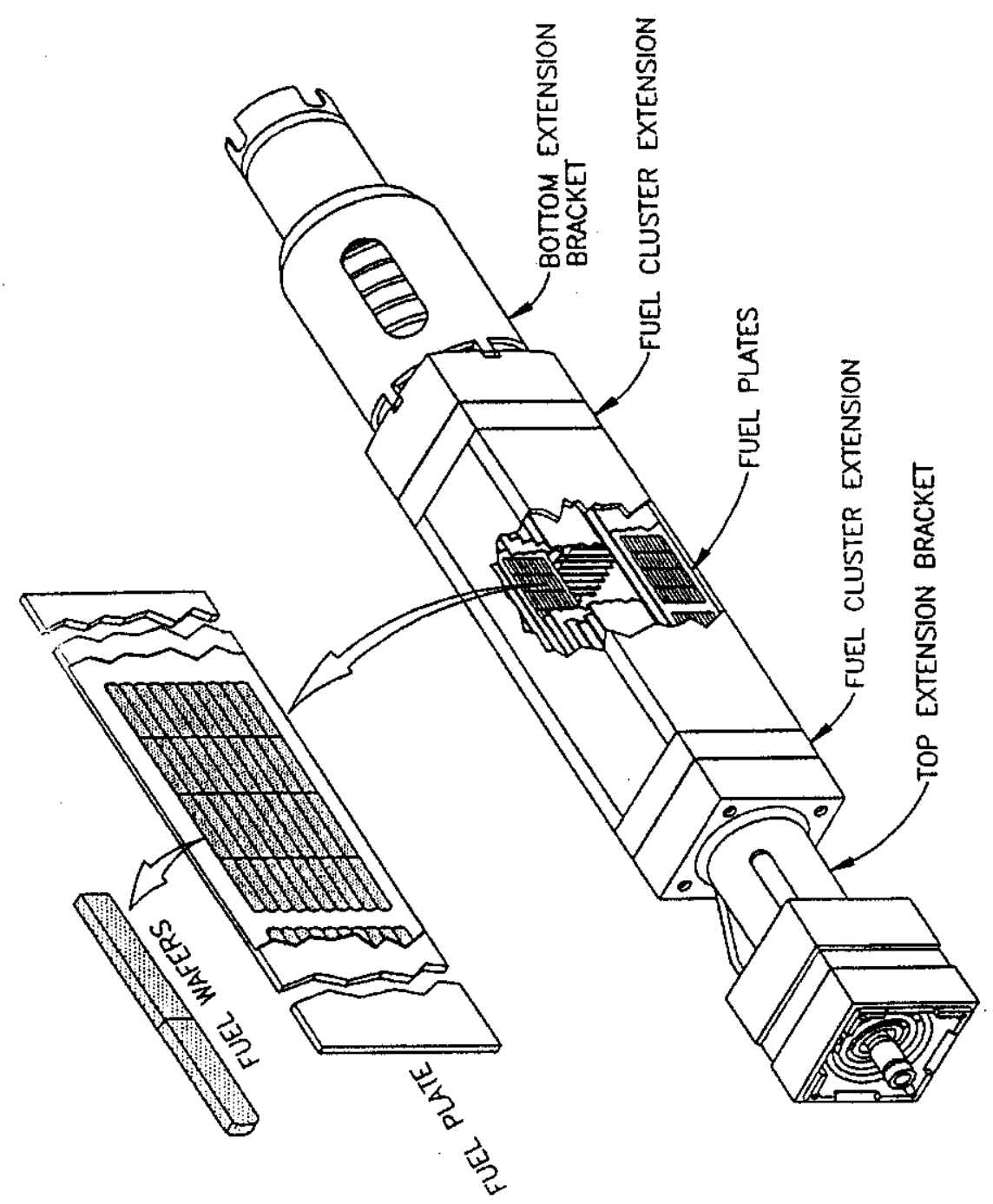




\subsection{METHODS}

\subsection{DOSE RATE CALCULATIONS FOR SHIPPINGPORT SPENT FUEL CANISTER OPERATIONS}

HNF-SD-SNF-TI-062, Shippingport Pressurized Water Reactor Core 2 Blanket Assemblies in Multi-Canister Overpack Shielding Calculations Using MCNP, provides the dose rate calculations using the enhanced source term data from HNF-SD-SNF-TI-061, Shippingport Pressurized Water Reactor Core 2 Blanket Assemblies Source Term Calculations Using ORIGEN2. HNF-SD-SNF-TI-061 provides the latest source term information, which updated the previous source term to include the following:

- Extended decay time.

- Change axial distribution of fission and activation products from an average over the length of the fuel assemblies to distribution based on experimental measurements.

- Addition of a nominal fuel assembly.

- Correction of hafnium concentration in Zircaloy fuel cladding.

Radiation dose rates were calculated using Monte Carlo n-particle (MCNP) transport computer codes for two decay times (January 1, 2001, and January 1, 2004). The calculations included gamma and neutron sources. The calculations considered radiation from fuel activation and activation products in the extension brackets. Geometries considered were: (1) an SSFC in a TN-WHC cask with and without a cask lid installed, and (2) the SSFC in air without a cask. (This document refers to the SSFC as an MCO). As previously noted, the two casks are identical externally; however, there are internal differences to accommodate the different fuel type.

A nominal SSFC loading (three assemblies at $\sim 13,800$ megawatt thermal days per metric ton uranium $\left[\mathrm{MW}_{\mathrm{t}} \mathrm{d} / \mathrm{MTU}\right]$ and one assembly at $\sim 24,600 \mathrm{MW} / \mathrm{MTM}$ ) will be established by operating procedures and TSR controls. This nominal loading is used for calculations in this analysis. Maximum loading (four assemblies at 24,600 MW/MTM) was also calculated and is included in Appendix A.

Table 2-1 through Table 2-4 summarize the MCNP radiation exposure data from HNF-SD-SNF-TI-062 using nominal fuel loading. Appendix A provides a similar summary using maximum fuel loading. 
Table 2-1. Source: Irradiated Uranium and Cladding Nominal Loading

Radial - Multi-Canister Overpack Inside Lidded Cask

\begin{tabular}{|l|c|c|c|c|c|c|}
\hline (mrem/hr) & $\begin{array}{c}\text { Shipping } \\
\text { cask } \\
\text { contact }\end{array}$ & $\mathbf{0 . 3} \mathbf{~ m}$ & $\mathbf{1 . 0} \mathbf{~ m}$ & $\mathbf{2 . 0} \mathbf{~ m}$ & $\mathbf{6 . 0} \mathbf{~ m}$ & $\mathbf{1 0 . 0} \mathbf{~ m}$ \\
\hline Gamma & 46 & 24 & 11 & 5 & 1 & 0.4 \\
\hline Neutron & 69 & 32 & 13 & 6 & 1 & 0.4 \\
\hline Total & 115 & 56 & 24 & 11 & 2 & 1 \\
\hline
\end{tabular}

Table 2-2. Source: Irradiated Uranium and Cladding Nominal Loading

Top - Multi-Canister Overpack Inside Lidded Cask

\begin{tabular}{|l|c|c|c|c|c|c|}
\hline & $\begin{array}{c}\text { Shipping } \\
\text { cask } \\
\text { contact }\end{array}$ & $\mathbf{0 . 3} \mathbf{m r e m} / \mathbf{h r})$ & $\mathbf{1 . 0} \mathbf{m}$ & $\mathbf{2 . 0} \mathbf{m}$ & $\mathbf{6 . 0} \mathbf{m}$ & $\mathbf{1 0 . 0} \mathbf{~ m}$ \\
\hline Gamma & 0.08 & 0.08 & 0.03 & 0.03 & 0.02 & 0.01 \\
\hline Neutron & 2.0 & 1.0 & 0.4 & 0.2 & 0.1 & 0.06 \\
\hline Total & 2.08 & 1.08 & 0.43 & 0.23 & 0.12 & 0.07 \\
\hline
\end{tabular}

Table 2-3. Source: Irradiated Uranium and Cladding Nominal Loading

Top - Multi-Canister Overpack Inside Cask, No Lid

\begin{tabular}{|l|c|c|c|c|c|c|}
\hline & $\begin{array}{c}\text { Shipping } \\
\text { cask } \\
\text { contact }\end{array}$ & $\mathbf{0 . 3} \mathbf{~ m}$ & $\mathbf{1 . 0} \mathbf{~ m}$ & $\mathbf{2 . 0} \mathbf{~ m}$ & $\mathbf{6 . 0} \mathbf{~ m}$ & $\mathbf{1 0 . 0} \mathbf{~ m}$ \\
\hline Gamma & 4.7 & 2.8 & 1.3 & 0.7 & 0.4 & 0.1 \\
\hline Neutron & 3.0 & 2.0 & 0.6 & 0.3 & 0.1 & 0.02 \\
\hline Total & 7.7 & 4.4 & 1.9 & 1.0 & 0.5 & 0.12 \\
\hline
\end{tabular}


SNF-5808, REV 0

Table 2-4. Gamma Source: Irradiated Top Extension Bracket

\begin{tabular}{|l|c|c|c|c|c|c|}
\hline \multicolumn{1}{|c|}{$(\mathbf{m r e m} / \mathbf{h r})$} & $\begin{array}{c}\text { Shipping } \\
\text { cask contact }\end{array}$ & $\mathbf{0 . 3} \mathbf{~ m}$ & $\mathbf{1 . 0} \mathbf{~ m}$ & $\mathbf{2 . 0} \mathbf{~ m}$ & $\mathbf{6 . 0} \mathbf{~ m}$ & $\mathbf{1 0 . 0} \mathbf{~ m}$ \\
\hline $\begin{array}{l}\text { Nominal } \\
\text { Loading-Lidded }\end{array}$ & 2 & 0.8 & 0.3 & 0.1 & 0.02 & 0.02 \\
\hline $\begin{array}{l}\text { Nominal } \\
\text { Loading- No Lid }\end{array}$ & 39 & 19 & 8 & 4 & 0.6 & 0.2 \\
\hline
\end{tabular}

FDH-788, SNF Canister Storage Building ALARA Analysis 09, is the most recent ALARA analysis for the CSB. This report provides maximum personnel exposure estimates for the first and second year of CSB operations. Based on the analysis, there appears to be a high probability that none of the operating personnel will exceed $1,000 \mathrm{mrem} / \mathrm{year}$ due to $\mathrm{MCO}$ handling operations. Therefore, the design objective from Title 10, Code of Federal Regulations, Part 835 (10 CFR 835), "Occupational Radiation Protection," for personnel exposures has been achieved. This ALARA analysis does not factor in an increased background dose during the handling and operations resulting from adding 18 SSFCs to the building inventory, as the operating area is well shielded from the vault beneath and the Shippingport PWR Core 2 fuel is only approximately $5 \%$ of the CSB inventory.

The primary method employed to estimate personnel exposure for each task is that of assigning a dose rate and time interval during which specified personnel are exposed to that dose rate. The sum of these products for all of the time intervals, dose rates, and personnel categories provides the cumulative dose received by all personnel to complete a task. The variables in this process include selecting the best estimates for task times and the dose rates present. Since dose rates are influenced by distance from the source and intervening shielding, the average dose rate is not easily determined. The MCNP simulation provides estimated dose rates at prescribed distances. Detailed time-motion studies of the tasks involved within the CSB are not available; however, an estimated step-by-step flow chart was provided in ALARA Analysis 09 (FDH-788) and is included as Appendix B. These estimated times were further refined by use of a program called Crystal Ball from Decisioneering, Incorporated, Denver, Colorado. This program accounts for the fact that personnel only spend a fraction of the task time in the greatest dose rate region. The remainder of the task time is spent in a lower dose rate region. Using these refined task times provides a more realistic estimate of personnel exposure.

The analysis for SSFC operations followed the same logic path as the MCO exposure analysis, substituting MCNP dose rate numbers for the Shippingport fuel. It should be noted that this analysis is conservatively high, as all steps used for the MCO were calculated for the SSFC. This results in additional steps not applicable for the SSFC being assessed, which also drives the total personnel exposure estimate higher. Nominal fuel loading in the SSFC will result in only one quadrant of the cask exhibiting the highest radiation levels. This allows workers a relatively low dose area to approach and work on the cask. Since only about $10 \%$ of the fuel is maximum burnup, and an administrative control will be used to insert the "nominal load" in accordance with the loading plan, it is defensible to assume nominal loading for realistic personnel exposure calculation. The personnel exposures calculated using the anticipated nominal fuel loading is provided in Table $2-5$. 
Table 2-5. One Year - Nominal Shippingport Spent Fuel Canister Exposure

\begin{tabular}{|l|c|c|c|c|}
\hline \multicolumn{1}{|c|}{ Crew member } & $\begin{array}{c}\text { Annual } \\
\text { cumulative } \\
\text { exposure } \\
\text { (person-mrem) }\end{array}$ & $\begin{array}{c}\text { Number in } \\
\text { crew }\end{array}$ & $\begin{array}{c}\text { Average annual } \\
\text { personnel exposure } \\
\text { (mrem/yr) }\end{array}$ & $\begin{array}{c}\text { Meet design } \\
\text { objective of } \\
<\mathbf{1 , 0 0 0 ~} \mathbf{~ m r e m} / \mathbf{y r}\end{array}$ \\
\hline Operators & 2,808 & 12 & 234 & Yes \\
\hline $\begin{array}{l}\text { Health Physics } \\
\text { Technicians }\end{array}$ & 1,008 & 8 & 126 & Yes \\
\hline Inspection Personnel & 1,887 & 8 & 236 & Yes \\
\hline Weld Personnel & 584 & 8 & 73 & Yes \\
\hline Drivers & 72 & 4 & 18 & Yes \\
\hline Total Crew & 6,359 & 40 & 159 & Yes \\
\hline
\end{tabular}

\subsection{RESULTS, OPTIONS, AND CONSIDERATIONS}

CSB personnel exposures from either $\mathrm{MCO}$ or SSFC receiving and handling operations will not exceed 1,000 mrem/year for any work crew member. Combining the two operations during a single year will not result in work crew members exceeding 1,000 mrem/year based on several assumptions. Several factors impact the cumulative exposure at the CSB, including the number of MCO receiving operations in a year, facility staffing level, installed facility shielding, and fuel loading of the SSFCs. Assuming an MCO handling rate of 170/year and nominal SSFC loading, and staffing levels as listed in Table 2-5, all work crew personnel will have an annual exposure of less than 1,000 mrem.

The following discussion explores several options or considerations that could reduce radiation exposure in the CSB.

\subsection{SHIELDING SHIPPINGPORT SPENT FUEL CANISTER}

Additional shielding for the SSFC was considered, but the design of the SSFC does not lend itself to additional external shielding. There is minimal room inside the SSFC that could be used to incorporate additional internal shielding. The amount of shielding that could be included would not substantially reduce the exposure, especially since the majority is from neutrons. Additional shielding attached outside the shipping cask would also have marginal effect on 
operations at the CSB, as the majority of the exposure is received after the SSFC is removed from the transport cask.

\subsection{SHIELDING IN THE CANISTER STORAGE BUILDING}

Additional shielding (temporary or permanent) at two operating stations, the receiving crane and the MCO handling machine (MHM), was considered. However, only marginal exposure savings can be gained at the receiving crane operation station. The total time this operator is exposed to the highest radiation field (approximately $27 \mathrm{mrem} / \mathrm{hr}$ ) is approximately one hour per container. Since the majority of the exposure is from neutrons, the thickness needed for any substantial decrease in dose rate, coupled with the relatively short duration, does not justify the cost of installation. The addition of a full 10-in. thickness of shielding would only result in an exposure reduction of approximately 54 mrem for the entire campaign.

The MHM operator will be exposed approximately three times as long in the radiation field as the receiving crane operator. The majority of the exposure from an SSFC to the MHM operator will be from gamma radiation. The unshielded dose rate two meters from the top of the SSFC is $424 \mathrm{mrem} / \mathrm{hr}$ and $228 \mathrm{mrem} / \mathrm{hr}$ at six meters. The MHM operator is provided shielding by the existing MHM design and is approximately three meters above the SSFC. The MHM operator would be exposed to only approximately $1.3 \mathrm{mrem} / \mathrm{hr}$. The design basis of the MHM operator for MCO radiation exposure was $0.5 \mathrm{mrem} / \mathrm{hr}$. The time frame coupled with the increase in dose rates resulted in consideration of additional shielding to minimize MHM operator exposure. If an additional $2 \mathrm{in.} \mathrm{of} \mathrm{steel} \mathrm{shielding} \mathrm{were} \mathrm{installed,} \mathrm{this} \mathrm{could} \mathrm{reduce}$ radiation exposure by approximately $30 \%$. However, the total radiation exposure savings would be insignificant. In addition, the MHM design might not accommodate this additional loading. The cost for these insignificant savings is therefore not justified.

No additional shielding is recommended for the walls of the CSB. There may be short duration time frames where exposures in routinely occupied spaces outside of the Receiving Area exceed posted limits (i.e., the fan room and the counting station). Administrative controls and temporary posting can deal with these occurrences in order to control exposures.

\subsection{NUMBER OF OPERATIONS PER YEAR}

One of the basic assumptions for the analysis was that the number of MCO cask operations estimated was fixed at 170 per year. The increase in radiation exposure from the SSFCs could be offset by a reduced number of MCO operations. Current discussions are considering variations of the MCO receiving operation period due to $\mathrm{MCO}$ fuel loading constraints at the $\mathrm{K}$ Basins. This could reduce the cumulative MCO personnel exposure by the percentage of MCO reduction during the year the SSFCs were handled. An additional decrease in MCO operations coupled with nominal SSFC fuel loading would achieve an additional reduction below the $1,000 \mathrm{mrem} /$ year limit for all categories of involved workers. 


\subsection{REFERENCES}

10 CFR 835, “Occupational Radiation Protection," Code of Federal Regulations.

FHD-788, 1998, SNF Canister Storage Building ALARA Analysis 09, Fluor Daniel Hanford, Incorporated, Richland, Washington.

HNF-SD-SNF-TI-061, 1999, Shippingport Pressurized Water Reactor Core 2 Blanket Assemblies Source Term Calculations Using ORIGEN2, Rev. 1, Fluor Daniel Northwest, Incorporated, Richland, Washington.

HNF-SD-SNF-TI-062, 1999, Shippingport Pressurized Water Reactor Core 2 Blanket Assemblies in Multi-Canister Overpack Shielding Calculations Using MCNP, Rev. 1, Fluor Daniel Northwest, Incorporated, Richland, Washington.

SNF-5809, 2000, Shippingport Spent Fuel Canister System Description, Fluor Hanford, Incorporated, Richland, Washington.

WAPD-296, 1968, PWR Core2 Reactor Design Description Report, Bettis Atomic Power Laboratory, Pittsburgh, Pennsylvania. 
SNF-5808, REV 0

This page intentionally left blank. 


\section{APPENDIX A \\ SHIPPINGPORT SPENT FUEL CANISTER EVALUATIONS FOR MAXIMUM FUEL LOADING}

This Appendix provides a summary of the Monte Carlo n-particle (MCNP) radiation exposure data from HNF-SD-SNF-TI-062, Shippingport Pressurized Water Reactor Core 2 Blanket Assemblies in Multi-Canister Overpack Shielding Calculations Using MCNP, for Shippingport Spent Fuel Canisters (SSFCs) with maximum fuel loading. The same methodology was used as in the body of this analysis. This Appendix provides a comparison between maximum and nominal fuel loading in an SSFC and the resultant cumulative work crew exposure. The table numbers correlate to table numbers in the body of the text.

Table A-1. Source: Irradiated Uranium and Cladding Maximum Loading

Radial - Multi-Canister Overpack Inside Lidded Cask

\begin{tabular}{|l|c|c|c|c|c|c|}
\hline & $\begin{array}{c}\text { Shipping } \\
\text { cask } \\
\text { contact }\end{array}$ & $\mathbf{0 . 3} \mathbf{~ m}$ & $\mathbf{1 . 0} \mathbf{~ m}$ & $\mathbf{2 . 0} \mathbf{~ m}$ & $\mathbf{6 . 0} \mathbf{~ m}$ & $\mathbf{1 0 . 0} \mathbf{~ m}$ \\
\hline Gamma & $\mathbf{7 8}$ & 41 & 18 & 9 & 2 & 1 \\
\hline Neutron & 204 & 94 & 39 & 18 & 3 & 1 \\
\hline Total & 282 & 135 & 57 & 27 & 5 & 2 \\
\hline
\end{tabular}

Table A-2. Source: Irradiated Uranium and Cladding Maximum Loading

Top - Multi-Canister Overpack Inside Lidded Cask

\begin{tabular}{|l|c|c|c|c|c|c|}
\hline & $\begin{array}{c}\text { Shipping } \\
\text { cask } \\
\text { contact }\end{array}$ & $\mathbf{0 . 3} \mathbf{~ m}$ & $\mathbf{1 . 0} \mathbf{~ m}$ & $\mathbf{2 . 0} \mathbf{~ m}$ & $\mathbf{6 . 0} \mathbf{~ m}$ & $\mathbf{1 0 . 0} \mathbf{~ m}$ \\
\hline Gamma & 0.1 & 0.1 & 0.06 & 0.04 & 0.03 & 0.01 \\
\hline Neutron & 7 & 3 & 1 & 0.6 & 0.3 & 0.2 \\
\hline Total & 7.1 & 3.1 & 1.06 & 0.64 & 0.33 & 0.21 \\
\hline
\end{tabular}


Table A-3. Source: Irradiated Uranium and Cladding Maximum Loading Top - Multi-Canister Overpack Inside Cask, No Lid

\begin{tabular}{|l|c|c|c|c|c|c|}
\hline (mrem/hr) & $\begin{array}{c}\text { Shipping } \\
\text { cask } \\
\text { contact }\end{array}$ & $\mathbf{0 . 3} \mathbf{~ m}$ & $\mathbf{1 . 0} \mathbf{~ m}$ & $\mathbf{2 . 0} \mathbf{~ m}$ & $\mathbf{6 . 0} \mathbf{~ m}$ & $\mathbf{1 0 . 0} \mathbf{~ m}$ \\
\hline Gamma & 7.5 & 4.4 & 2.1 & 1.3 & 0.2 & 0.1 \\
\hline Neutron & $\mathbf{8}$ & 4 & 2 & 0.9 & 0.3 & 0.2 \\
\hline Total & 15.5 & 8.4 & 4.1 & 2.2 & 0.5 & 0.3 \\
\hline
\end{tabular}

Table A-4. Gamma Source: Irradiated Top Extension Bracket

\begin{tabular}{|l|c|c|c|c|c|c|}
\hline & $\begin{array}{c}\text { Shipping } \\
\text { cask } \\
\text { contact }\end{array}$ & $\mathbf{0 . 3} \mathbf{~ m}$ & $\mathbf{1 . 0} \mathbf{~ m}$ & $\mathbf{2 . 0} \mathbf{~ m}$ & $\mathbf{6 . 0} \mathbf{~ m}$ & $\mathbf{1 0 . 0} \mathbf{~ m}$ \\
\hline $\begin{array}{l}\text { Max. } \\
\text { Loading- } \\
\text { Lidded }\end{array}$ & 3 & 1 & 0.4 & 0.2 & 0.03 & 0.02 \\
\hline $\begin{array}{l}\text { Max. } \\
\text { Loading-No } \\
\text { Lid }\end{array}$ & 56 & 27 & 11 & 5 & 0.9 & 0.3 \\
\hline
\end{tabular}


Table A-5. One Year - Maximum Shippingport Spent Fuel Canister Exposure

\begin{tabular}{|l|c|c|c|c|}
\hline & $\begin{array}{c}\text { Annual } \\
\text { cumulative } \\
\text { exposure } \\
\text { Crew member }\end{array}$ & $\begin{array}{c}\text { Number in } \\
\text { crew }\end{array}$ & $\begin{array}{c}\text { Average } \\
\text { annual } \\
\text { personnel } \\
\text { exposure } \\
\text { (mrem/yr) }\end{array}$ & $\begin{array}{c}\text { Meet design } \\
\text { objective of } \\
<\mathbf{1 , 0 0 0} \\
\mathbf{m r e m} / \mathbf{y r}\end{array}$ \\
\hline Operators & 7,020 & 12 & 585 & Yes \\
\hline $\begin{array}{l}\text { Health Physics } \\
\text { Technicians }\end{array}$ & 2,520 & 8 & 315 & Yes \\
\hline $\begin{array}{l}\text { Inspection } \\
\text { Personnel }\end{array}$ & 4,716 & 8 & 590 & Yes \\
\hline Weld Personnel & 1,458 & 8 & 183 & Yes \\
\hline Drivers & 180 & 4 & 45 & Yes \\
\hline Total Crew & 15,894 & 40 & 398 & Yes \\
\hline
\end{tabular}


SNF-5808, REV 0

This page intentionally left blank. 
SNF-5808, REV 0

\section{APPENDIX B \\ OPERATIONAL SEQUENCE BLOCK FLOW DIAGRAMS}

These seven operational sequence block flow diagrams are included to capture the process step timing and sequence used in this ALARA analysis. They were developed by CSB personnel through time/motion studies and are updated as process refinements are obtained. 


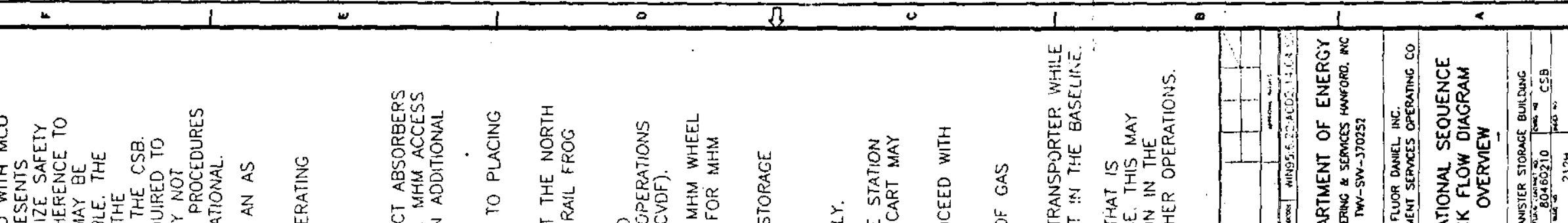

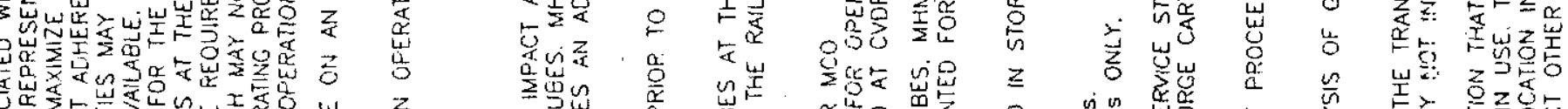

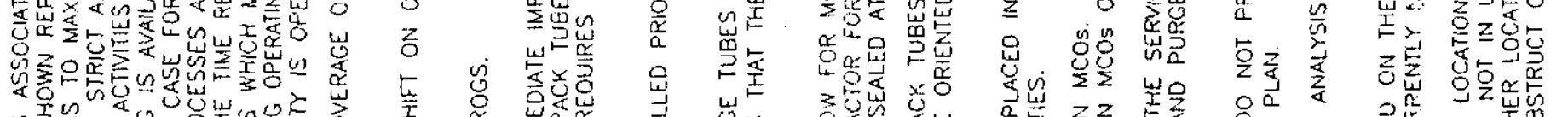

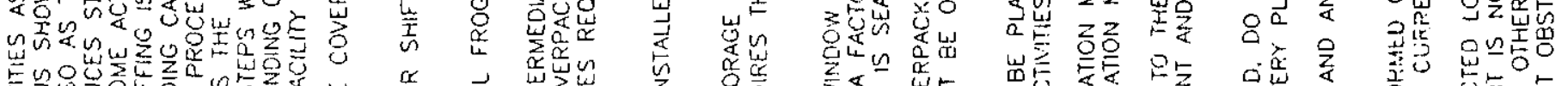

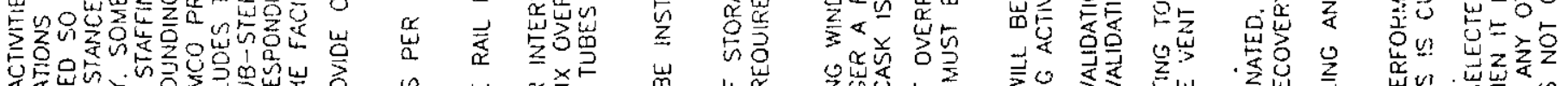

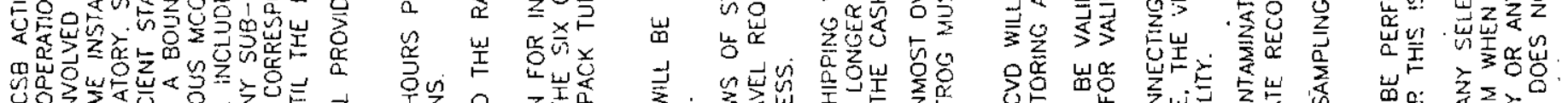

$\begin{array}{llll} & \\ 0 & \end{array}$

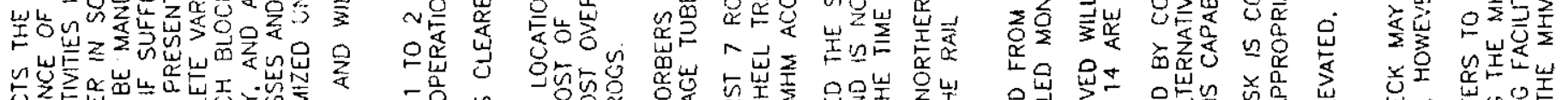

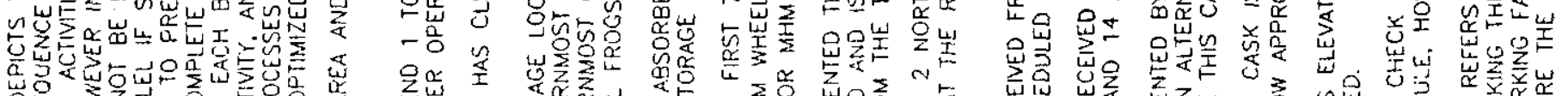

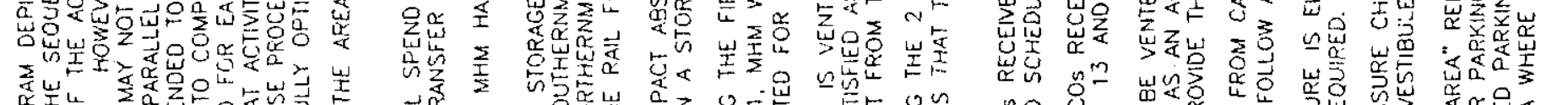

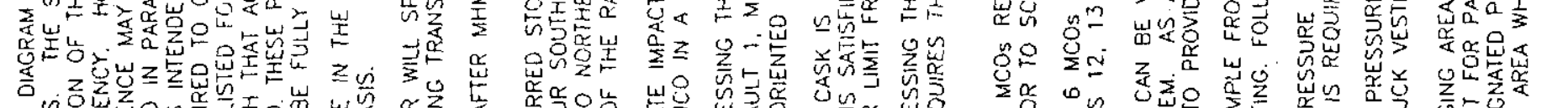

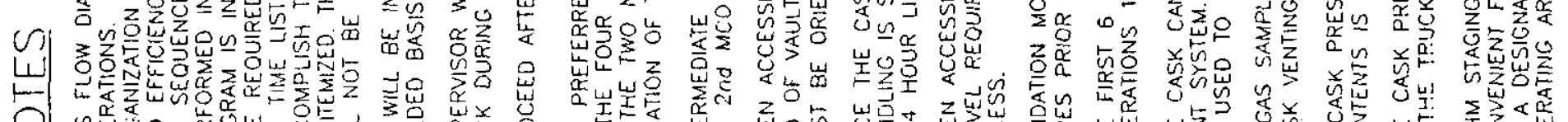

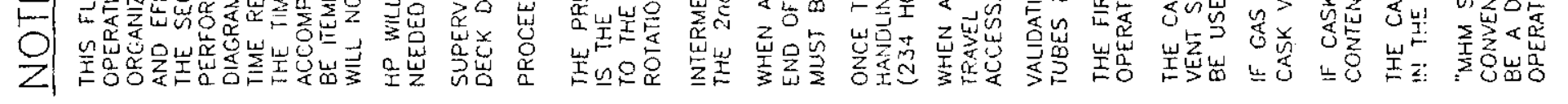

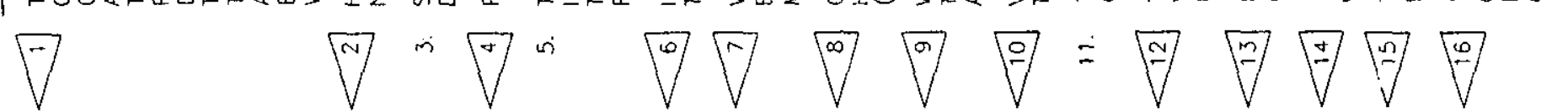
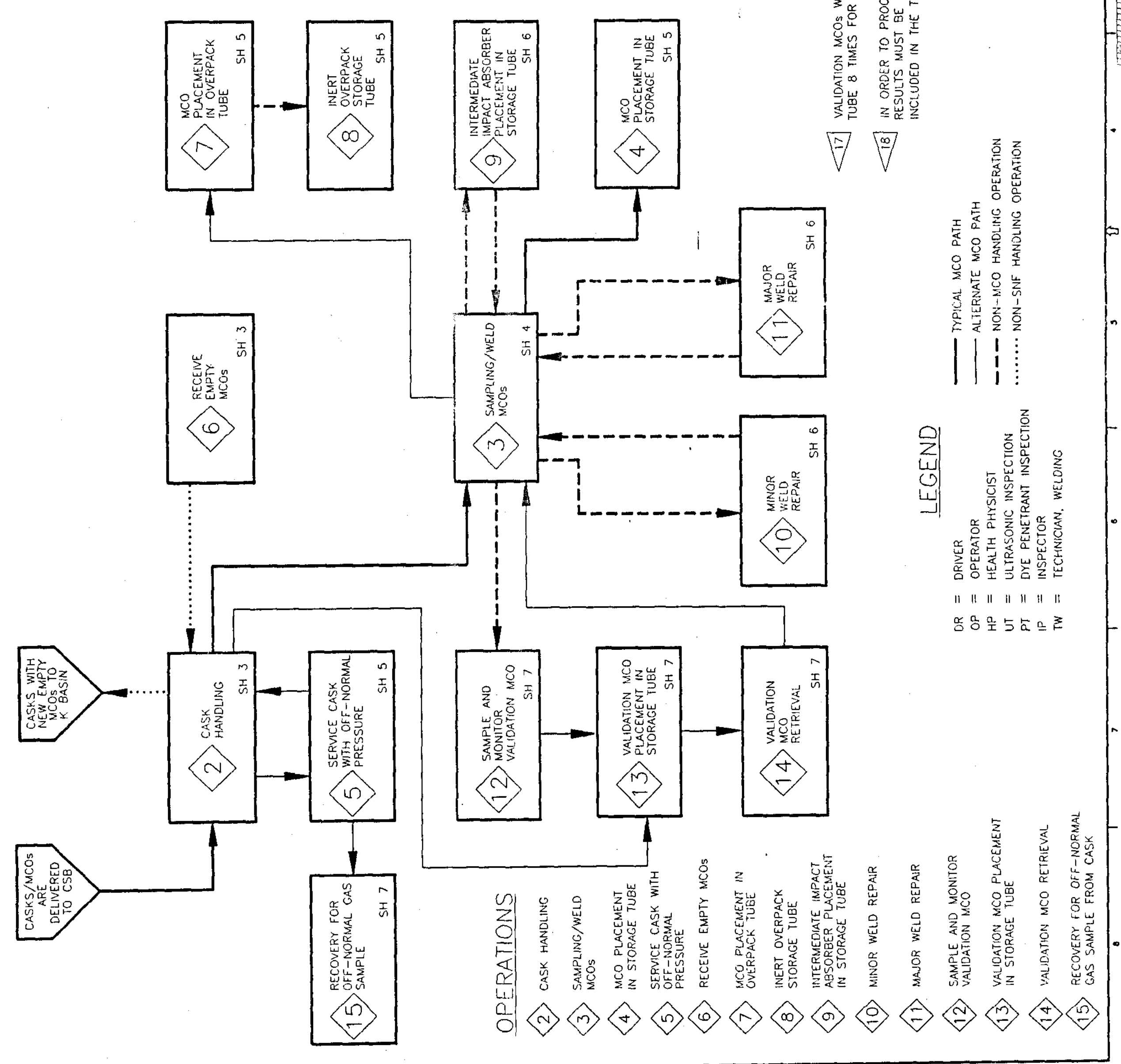

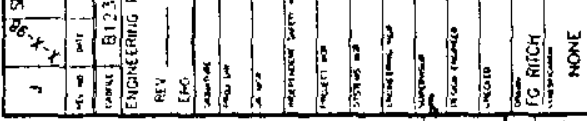
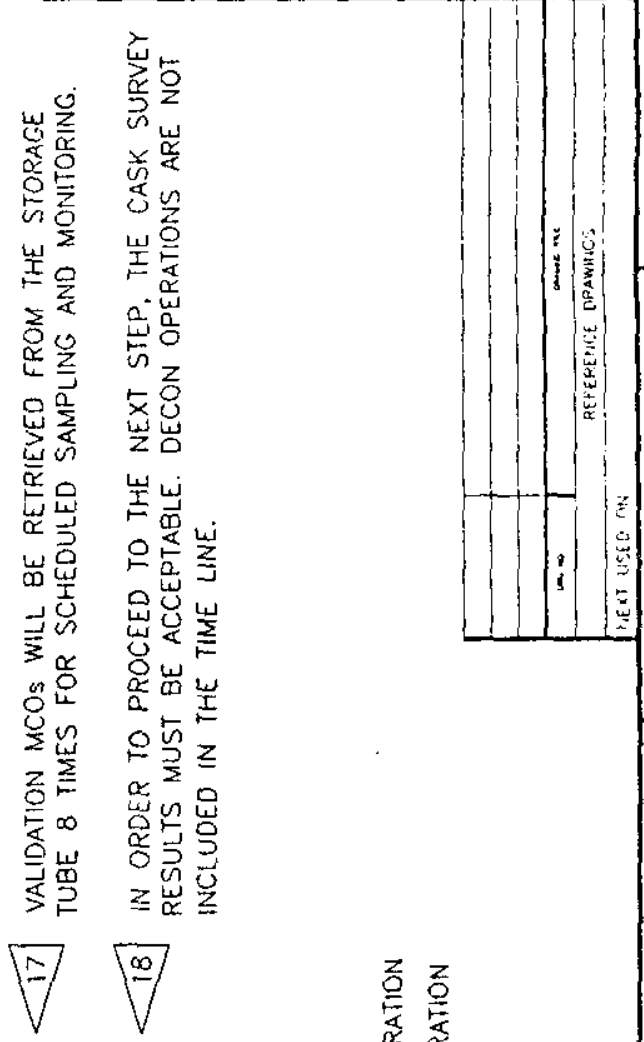


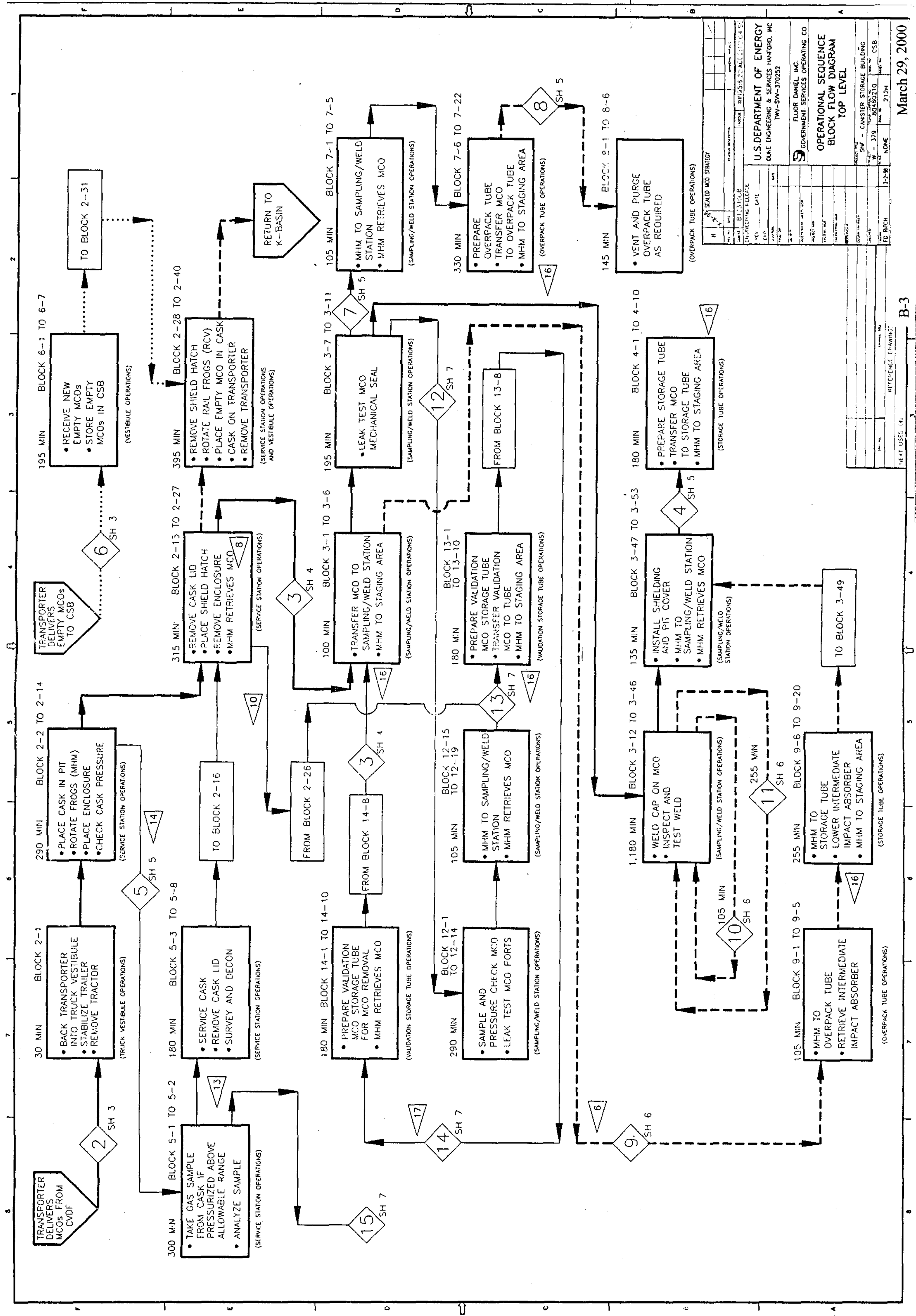




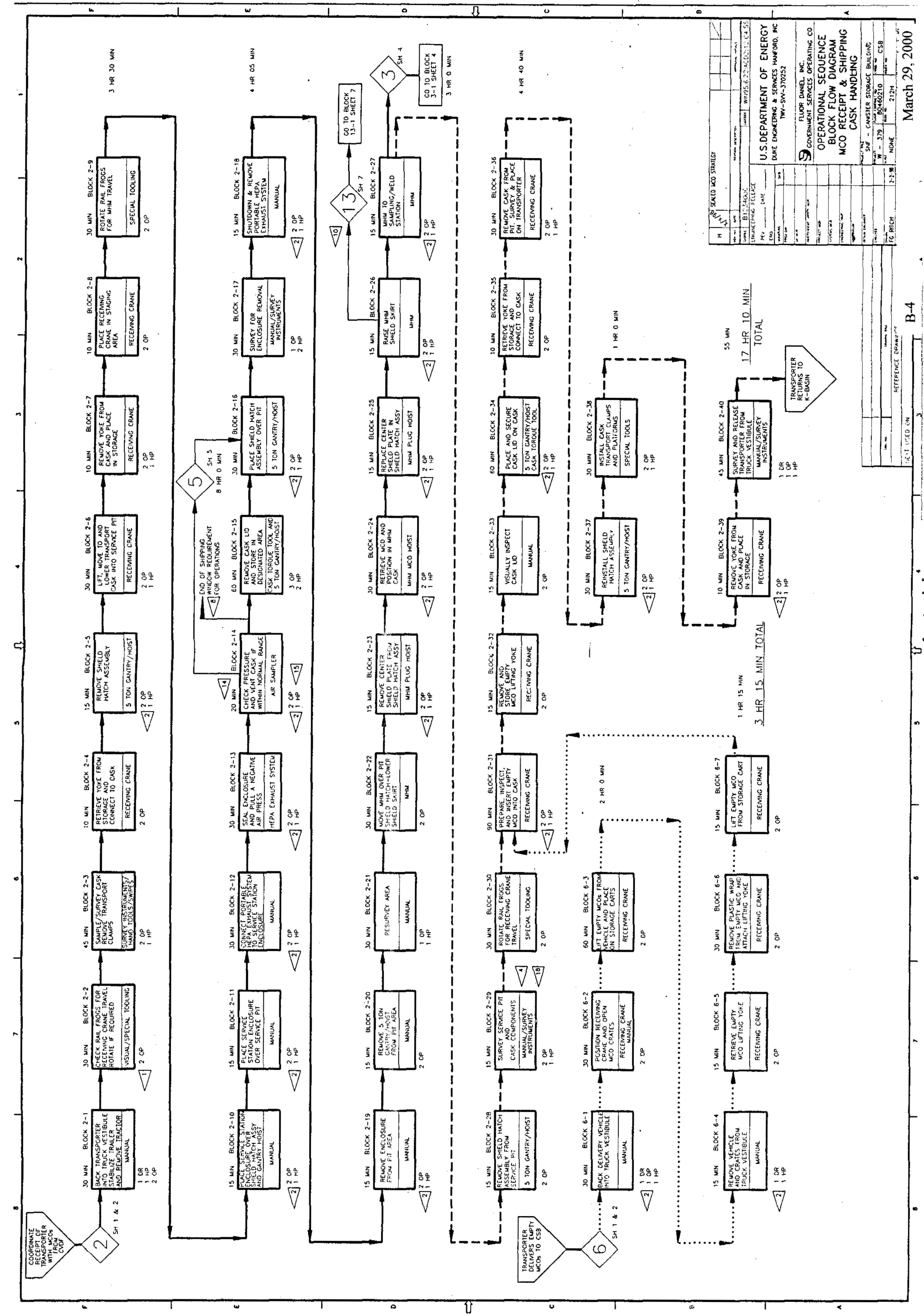




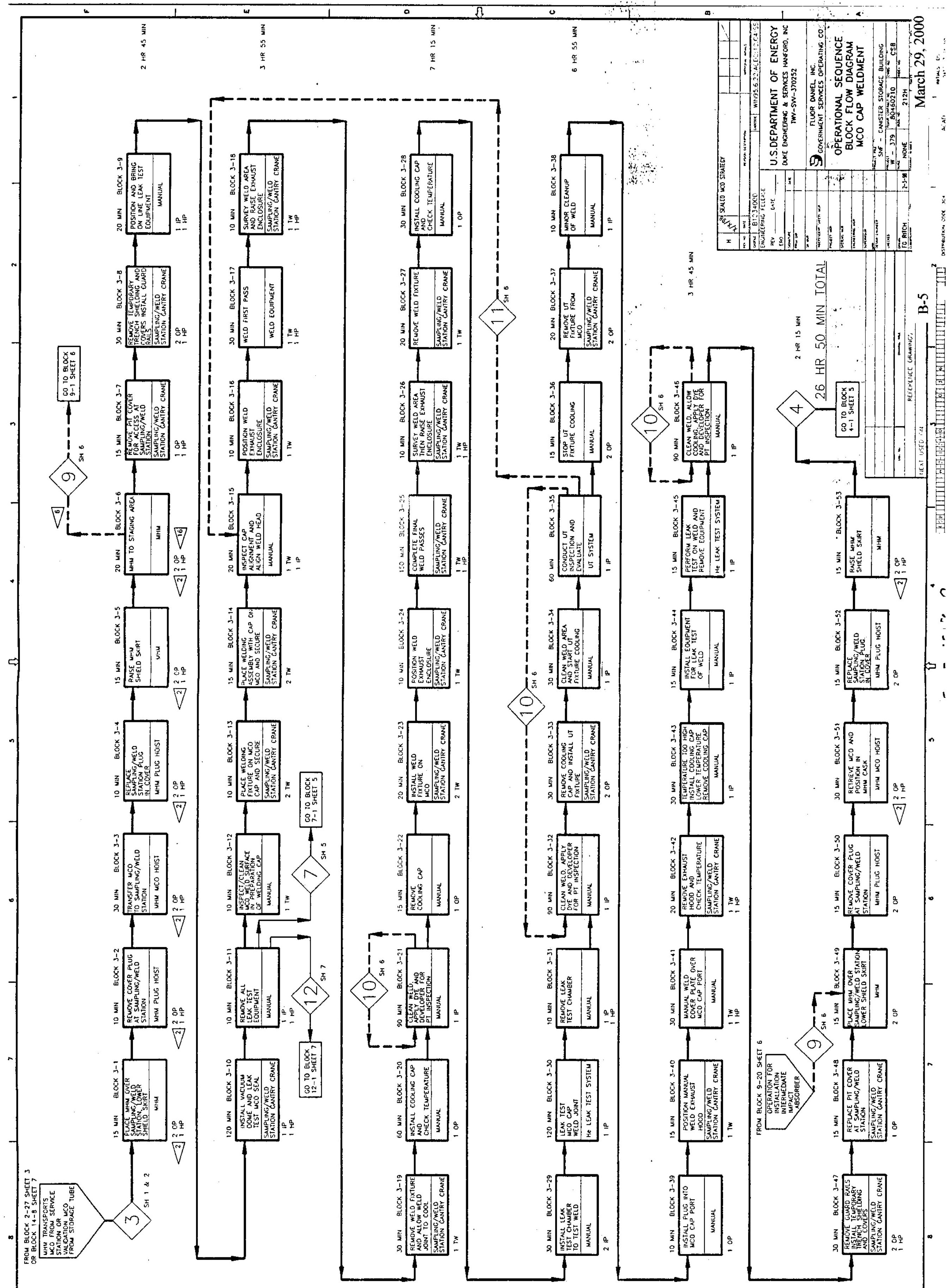




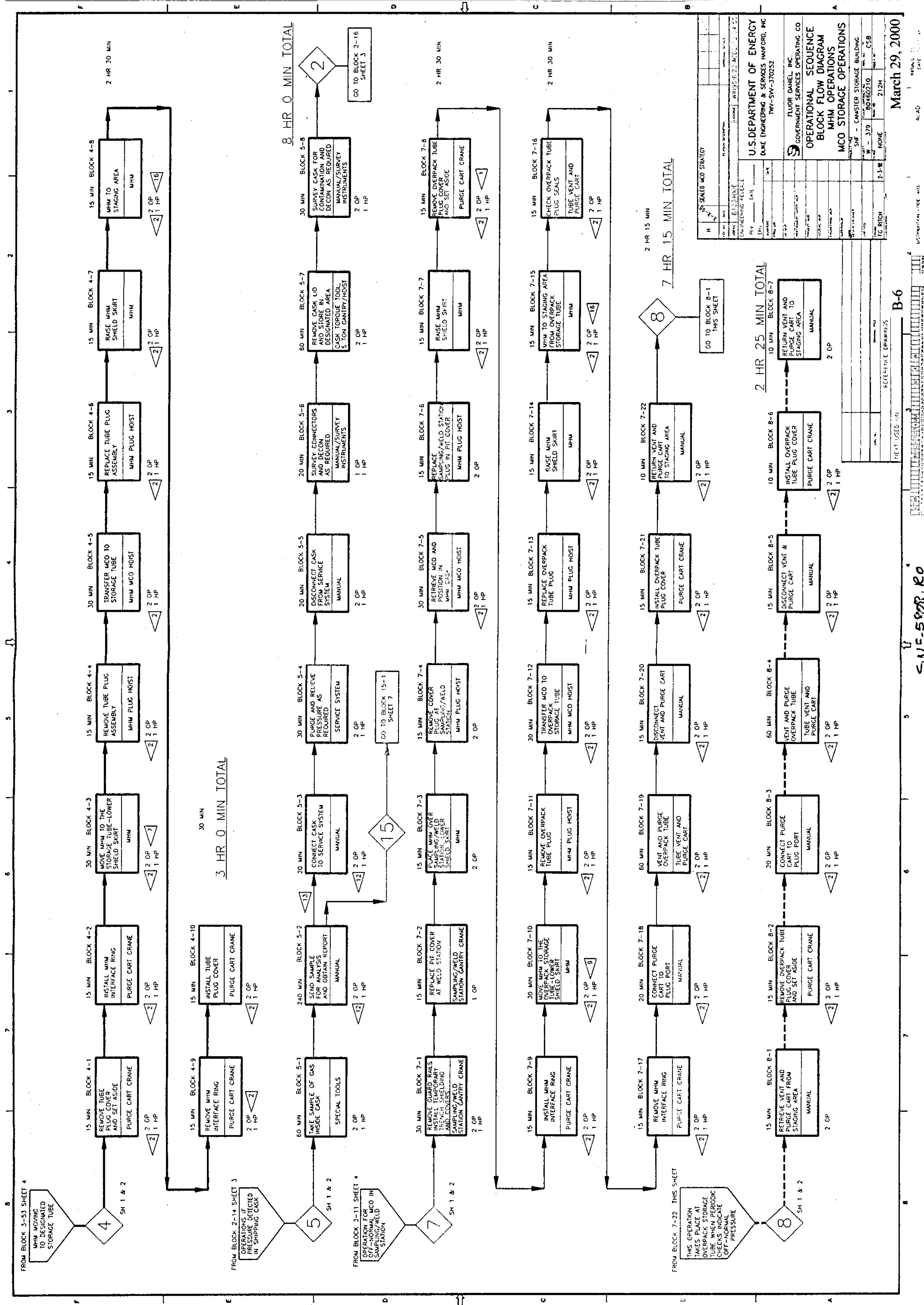




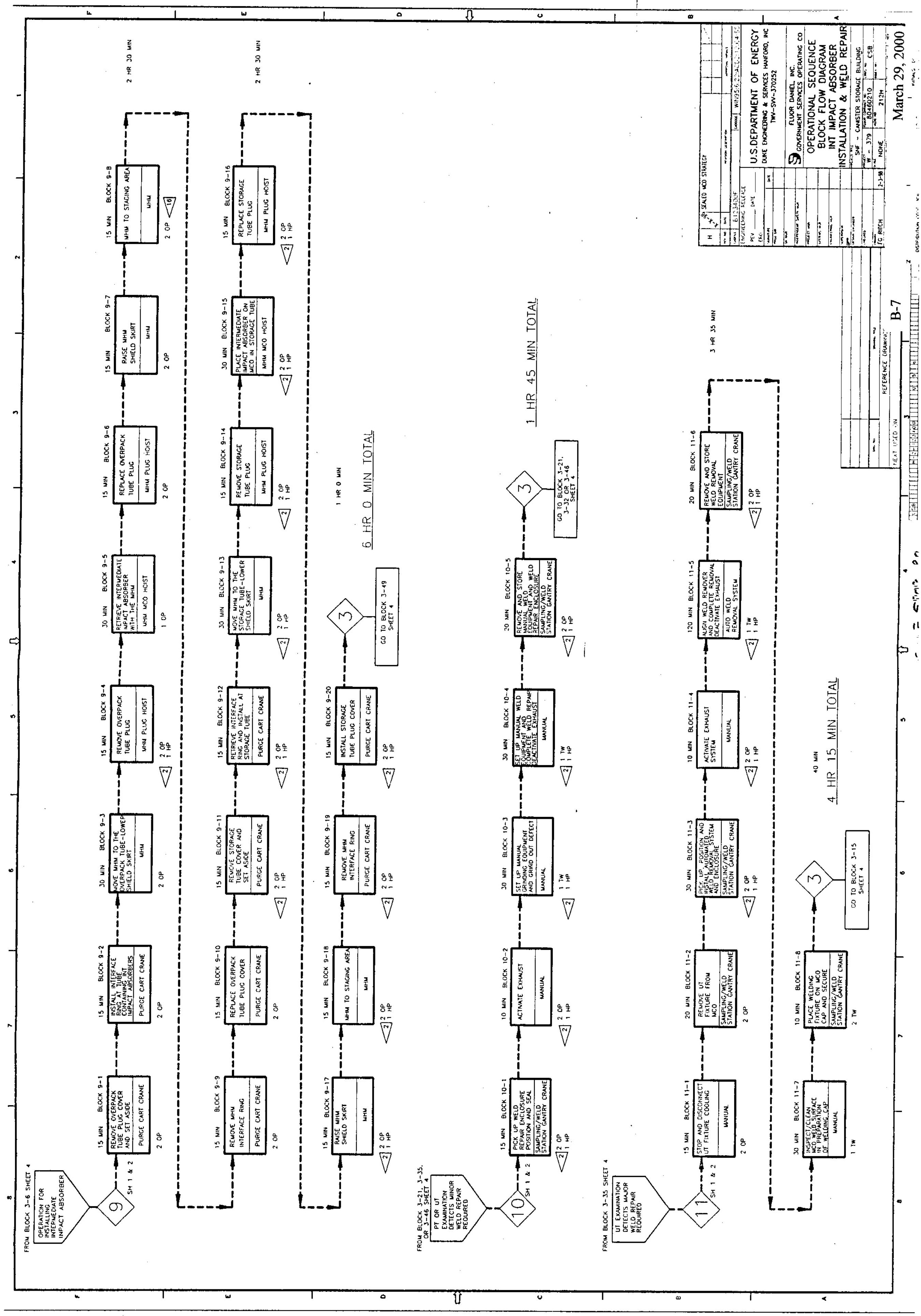




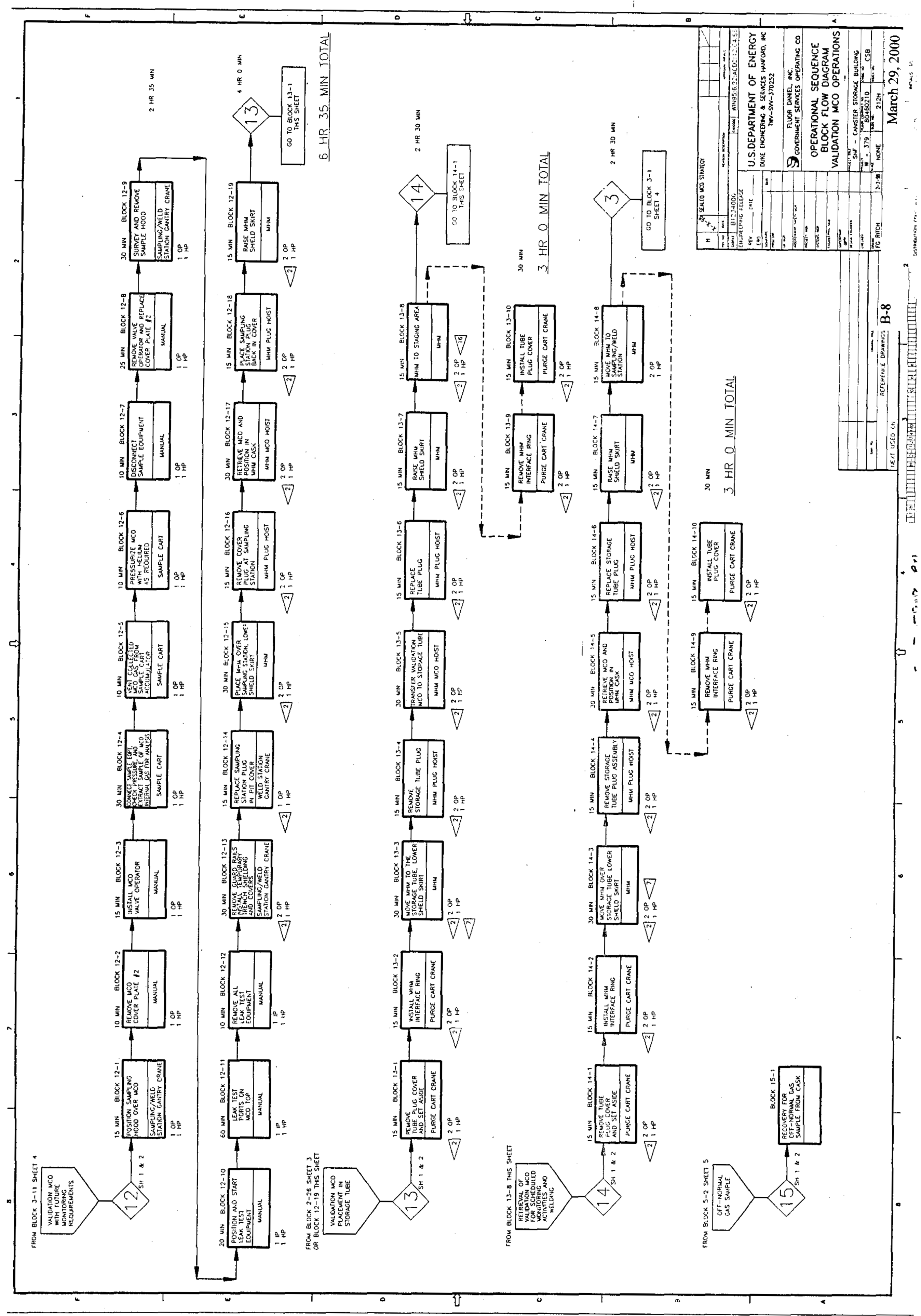




\section{DISTRIBUTION SHEET}

\begin{tabular}{|c|c|c|c|c|c|}
\hline \multirow{2}{*}{$\begin{array}{l}\text { To } \\
\text { Distribution }\end{array}$} & \multirow{2}{*}{\multicolumn{3}{|c|}{$\begin{array}{l}\text { From } \\
\text { Site-Wide SNF project }\end{array}$}} & \multicolumn{2}{|l|}{ Page 1 of 1} \\
\hline & & & & \multicolumn{2}{|l|}{ Date $3 / 29 / 00$} \\
\hline \multicolumn{4}{|l|}{ Project Title/Work Order } & \multicolumn{2}{|c|}{ EDT No. 629068} \\
\hline SNF-5808, Rev. 0 & & & & \multicolumn{2}{|l|}{ ECN No. N/A } \\
\hline \multicolumn{6}{|c|}{$\begin{array}{l}\text { ALARA Analysis for Shippingport Pressurized Water Reactor Core } 2 \text { Fuel } \\
\text { Storage in the Canister Storage Building }\end{array}$} \\
\hline Name & MSIN & $\begin{array}{l}\text { Text } \\
\text { With All } \\
\text { Attach. }\end{array}$ & Text Only & $\begin{array}{l}\text { Attach./ } \\
\text { Appendix } \\
\text { Only }\end{array}$ & $\begin{array}{c}\text { EDT/ECN } \\
\text { Only }\end{array}$ \\
\hline G. D. Bazinet & S8-06 & $\mathrm{X}$ & & & \\
\hline C. A. Bullock & X3-68 & $\mathrm{X}$ & & & \\
\hline B. A. Craig (library) & R3-26 & $\mathrm{X}$ & & & \\
\hline R. D. Carrell & R3-11 & $X$ & & & \\
\hline R. L. Garrett & R3-26 & $\mathrm{X}$ & & & \\
\hline D. M. Johnson & R3-11 & $\mathrm{X}$ & & & \\
\hline M. Lewis & B $1-41$ & $X$ & & & \\
\hline Y. J. Liu & R3-26 & $\mathrm{X}$ & & & \\
\hline B. D. Lorenz & $R 3-26$ & $\mathrm{X}$ & & & \\
\hline R. L. McCormack & R3-11 & $X$ & & & \\
\hline O. D. Serrano & R3-86 & $\mathrm{X}$ & & & \\
\hline D. W. Smith & $\mathrm{S} 2-48$ & $\mathrm{X}$ & & & \\
\hline SNF Project Files & R3-11 & $\mathrm{X}$ & & & \\
\hline
\end{tabular}

